Thermal Properties

\author{
L. C. Myers
}

DEVELOPMENT DIVISION

JULY - SEPTEMBER 1975

SANL NO. 458-019

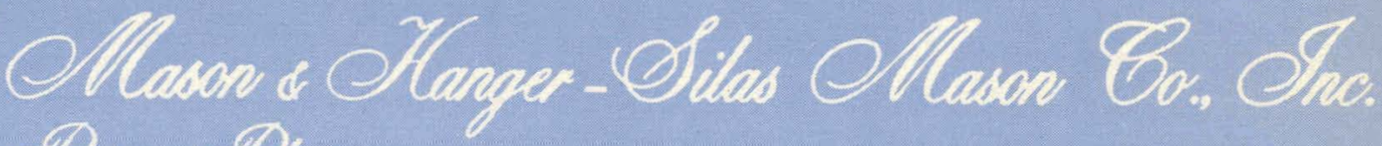

P. 0. $80 x 647$

AMARIIO, TKXIS 79177

$806-335-1581$ operated for the

ENEREY RESEARCH ANO DEVELOPMENT ADMINISTRATION under

U. S. GOVERNMENT Contract DA. $11 \cdot 173 \cdot$ AMC. $487(A)$ 


\section{DISCLAIMER}

This report was prepared as an account of work sponsored by an agency of the United States Government. Neither the United States Government nor any agency Thereof, nor any of their employees, makes any warranty, express or implied, or assumes any legal liability or responsibility for the accuracy, completeness, or usefulness of any information, apparatus, product, or process disclosed, or represents that its use would not infringe privately owned rights. Reference herein to any specific commercial product, process, or service by trade name, trademark, manufacturer, or otherwise does not necessarily constitute or imply its endorsement, recommendation, or favoring by the United States Government or any agency thereof. The views and opinions of authors expressed herein do not necessarily state or reflect those of the United States Government or any agency thereof. 


\section{DISCLAIMER}

Portions of this document may be illegible in electronic image products. Images are produced from the best available original document. 


\section{NOTICE}

This report was prepared as an account of work sponsored by the United States Government. Neither the United States nor the United States Energy Research and Development Administration, nor their employees, nor any of their contractors, subcontractors, or their employees, makes any warranty, express or implied, or assumes any legal liability or responsibility for the accuracy, completeness or usefulness of any information, apparatus, product or process disclosed, or represents that its use would not infringe privately-owned rights. 


\title{
Thermal Properties
}

\author{
L. C. Myers.
}

DEVELOPMENT DIVISION

July - September 1975

SANT, No. 45R-01?

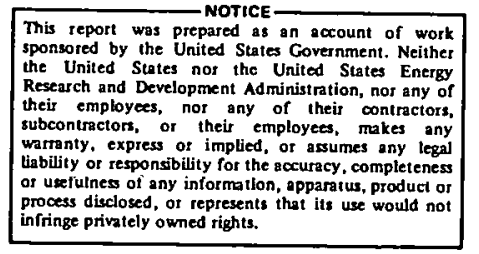

$B-1$ 


\section{ABSTRACT}

A complete series of thermal tests was made to evaluate the compatibility of $L X-10$ and $R X-03-B B$ with three new adhesives. The adhesives were special formulations prepared by $L$. P. Althouse and $H$. George Hammon of LLL. There was no indication that the adhesives were reactive with $R X-$ 03-BB at temperatures below $423 \mathrm{~K}$. With $L X-10$. there was an indication that two of the adhesives were slightly reactive at $393 \mathrm{~K}$.

Thermal decomposition data for PETN samples with different particle sizes are compared, and at $393 \mathrm{~K}$ the decomposition rate is particle size dependent, but at $383 \mathrm{~K}$ the rate is independent of particle size.

An investigation of the variations in the chemical reactivity test data has shown that part of the variations result from a change in the sensitivity of the instrument's detector. Tests were conducted on a gas mixture and PBX 9404 over a period of eight days and the standard deviation for the total volume of gas evolved from PBX 9404. was $3.8 \%$. By normalizing the PBX 9404 data us ing the gas mixture data, the standard deviation was reduced to $1.3 \%$.

\section{DISCUSSION}

Pantex was requested to conduct a complete series of thermal analys is tests on three new adhesives with $L X-10$ and RX-03-BB. The synthes is of the adhesives is described in an LLL Chemistry Department technical note by $L$. D. Althouse and H. George Hammon $(1,2)$.

Samples of each of the three adhesives were mixed and allowed to cure for more than five days at ambient temperature before testing. Their mixing ratios are given in Table I. The chemical reactivity test data for: the three adhesives with $L X-10$ and $R X-03-B B$ are given in Table II. The data for $L X-10$ with LPA-19-87/TONOX and LPA-19-73/HGH-18 show a small increase in the amount of $\mathrm{N}_{2} \mathrm{O}$ evolved indicating that there is some reactivity between the adhesive and the explosive. There is no indication of any reactivity between $R X-03-B B$ and any of the three adhesives.

Thermogravimetric analyses (TA) were made on each adhesive, the explosives, and a mixture of the adhesives with the explosive. Fig. 1 shows thermograms for LPA-19-73/HGH-14 and LPA-19-87/HGH-18. The initial weight loss ending near $373 \mathrm{~K}$ is from absorbed water. There were $0.45 \%$, $0.8 \%$, and $0.5 \%$ of absorbed water on samples LPA-19-73/HGH-14, LPA-19-87/ HGH-18, and LPA-19-87/TONOX, respectively. The thermograms al so show a difference in their thermal stability. LPA-19-73/HGH-14 is more stable than LPA-19-73/HGH-18 which has essentially the same stability as LPA19-87/TONOX. The TA thermograms given in Fig. 2 show that the decomposition

(1) L. P. Althouse and H. George Hammon, New Adhesive Synthesis I, Chemistry Department, Technical Note No. 75-23.

(2). L. P. Althouse and H. George Harmon, New Adhesive Synthesis II, Chemistry Department, Technical Note No. 75-24. 
temperature of $\mathrm{RX}-03-\mathrm{BB}$ is lowered by $65 \mathrm{~K}$ when mixed with either LPA-19-89/TONOX or LPA-19-87/HGH-18. LPA-19-73/HGH-14 reduced the decomposition temperature by $50 \mathrm{~K}$.

When the adhesives are mixed with $L X-10$ the decomposition temperature is reduced about $20 \mathrm{~K}$ in each case. This indicates that the explosives are reactive with the adhesive at elevated temperatures but it is not an indication that they are reactive at lower temperatures (< $393 \mathrm{~K}$ ). Similar lowering of the HMX decomposition temperature has been observed with other urethanes such as Adiprene $L-100$. ' Since Adiprene $L-100$ is known to be compatible with other HMX-Viton formulations the lowering of the decomposition temperature of $L X-10$ is not considered to be an indication of incompatibility.

Effluent Gas Analysis (EGA) thermograms were also obtained for the three adhesives, the explosives and their mixtures. Typical EGA thermograms of an adhesive (LPA-19-73/ HGH-18), LX-10 and a mixture of the two are shown in Fig. 3 and on comparing these thermograms it is seen that the decomposition of the mixture starts at a lower temperature (between 473 and $498 \mathrm{~K}$ ) but this is not considered to be an indication of incompatibility because other urethane adhesives such as Adiprene L-100 have a similar effect.

Fig. 4 shows the EGA thermograms of RX-03-BB and LPA-19-73/HGH-18. The decomposition temperature of the $R X-03-B B$ is lower in the presence of the adhesive.

The EGA thermograms show no indication that any of the three adhesives would be reactive with the two explosives at temperatures below $393 \mathrm{~K}$.

DTA thermograms were also obtained for the adhesive and the two explosives and the only abnormality observed with $L X-10$ was in the mixture with LPA-19-87/TONOX which has two exotherms (Fig. 5). This was not observed with the other two adhesives.

The DTA thermogram of RX-03-BB has only one exotherm but when mixed with any of the three adhesives twn exotherms are present, a larger followed by a smaller one, as shown in Fig. 6. The DTA thermograms show a lowering of the explosive's decomposition temperature which agrees with the TA and EGA data.

Henkins time to explosion data were obtained for each of the adhesives with LX-10. These data are given in Table III and a plot of the log of the harmonic mean as a function of the reciprocal of the absolute temperature is given in Fig. 7. From these data it is evident that LPA$19-73 / \mathrm{HGH}-14$ and $L P A=19-73 / \mathrm{HGH} 18$ are about equally reactive with $L X-10$ and LPA-19-87/TONOX and is the most reactive at these test temperatures.

The upper temperature limit of Pantex's standard Henkin apparatus is $573 \mathrm{~K}$. Time to explosion tests were made on RX-03-BB and after $1200 \mathrm{sec}$ at $573 \mathrm{~K}$ no explosions were obtained. Therefore, RX-03-BB could not be evaluated in the standard Henkin test apparatus. 
Two-gram samples of each of the adhesives were extracted for 24 hours with acetone and benzene using a soxhlet apparatus. The percentage extractables are given in Table IV. LPA-19-87/TONOX had the least and LPA-19-73/HGH-14 the greatest amount of extractables. 
$\therefore$ Table I. Mixing Ratio for the Three LLL Adhesives

(Percentage Composition by Weight)

\begin{tabular}{ccc}
\multicolumn{3}{c}{$\because$ Resin } \\
\hline LPA-19-73 & $\cdots$ & $\frac{\text { LPA-19-87 }}{67.0}$ \\
65.6 & $\ddots$ & - \\
& & -
\end{tabular}

93.0

\begin{tabular}{ccc}
\multicolumn{3}{c}{ Curing Agent } \\
\hline HGH-14 & HGH-18 & $\begin{array}{c}\text { TONOX } \\
(60 / 40)\end{array}$ \\
33.0 & $-\quad$ & - \\
- & 34.4 & - \\
- & - & 7.0
\end{tabular}


Table II. Chemical Reactivity Test Data for LX-10 and RX-03-BB wi th Three Adhesives

(me of gas corrected to STP)

(Samples conditioned at $393 \cdot \mathrm{K}$ for 22 Hrs)

\begin{tabular}{|c|c|c|c|c|c|c|}
\hline & $\mathrm{N}_{2}$ & co & NO & $\mathrm{CO}_{2}$ & $\mathrm{~N}_{2} \mathrm{O}$ & Total. \\
\hline$L X-10$ & $\begin{array}{l}0.006 \\
0.003\end{array}$ & $\begin{array}{l}-0- \\
-0-\end{array}$ & $\begin{array}{l}-0- \\
-0-\end{array}$ & $\begin{array}{l}0.001 \\
0.001\end{array}$ & $\begin{array}{l}0.002 \\
0.003\end{array}$ & $\begin{array}{l}0.009 \\
0.007\end{array}$ \\
\hline LPA-19-73/HGH-14 & $\begin{array}{l}0.007 \\
0.006\end{array}$ & $\begin{array}{l}-0- \\
-0-\end{array}$ & $\begin{array}{l}-0- \\
-0-\end{array}$ & $\begin{array}{l}0.016 \\
0.015\end{array}$ & $\begin{array}{l}-0- \\
-0-\end{array}$ & $\begin{array}{l}0.023 \\
0.021\end{array}$ \\
\hline $\begin{array}{l}\text { LX-10 with } \\
\text { LPA-19-73/HGGH-14 }\end{array}$ & $\begin{array}{l}0.005 \\
0.001\end{array}$ & $\begin{array}{l}-0- \\
-0-\end{array}$ & $\begin{array}{l}-0- \\
-0-\end{array}$ & $\begin{array}{l}0.017 \\
0.009\end{array}$ & $\begin{array}{l}0.003 \\
0.003\end{array}$ & $\begin{array}{l}0.025 \\
0.013\end{array}$ \\
\hline LPA-19-87/TONOX $(60 / 40)$ & $\begin{array}{l}0.003 \\
0.005\end{array}$ & $\begin{array}{l}-0- \\
-0-\end{array}$ & $\begin{array}{l}-0- \\
-0-\end{array}$ & $\begin{array}{l}0.003 \\
0.004\end{array}$ & $\begin{array}{l}-0- \\
-0-\end{array}$ & $\begin{array}{l}0.006 \\
0.009\end{array}$ \\
\hline $\begin{array}{l}\text { LX-10 with } \\
\text { LPA-19-87/TONOX }(60 / 40)\end{array}$ & $\begin{array}{l}0.009 \\
0.007\end{array}$ & $\begin{array}{l}-0- \\
-0-\end{array}$ & $\begin{array}{l}-0- \\
-0-\end{array}$ & $\begin{array}{l}0.008 \\
0.007\end{array}$ & $\begin{array}{l}0.017 \\
0.017\end{array}$ & $\begin{array}{l}0.034 \\
0.031\end{array}$ \\
\hline LPA-19-73/HGH-18 & $\begin{array}{l}0.007 \\
0.008\end{array}$ & $\begin{array}{l}-0- \\
-0-\end{array}$ & $\begin{array}{l}-0- \\
-0-\end{array}$ & $\begin{array}{l}0.033 \\
0.036\end{array}$ & $\begin{array}{l}-0- \\
-0-\end{array}$ & $\begin{array}{l}0.040 \\
0.044\end{array}$ \\
\hline $\begin{array}{l}\text { LX-10 with } \\
\text { LPA-19-73/HGH-18 }\end{array}$ & $\begin{array}{l}0.009 \\
0.012\end{array}$ & $\begin{array}{l}-0- \\
-0-\end{array}$ & $\begin{array}{l}-0- \\
-0-\end{array}$ & $\begin{array}{l}0.052 \\
0.058\end{array}$ & $\begin{array}{l}0.027 \\
0.023\end{array}$ & $\begin{array}{l}0.088 \\
0.093\end{array}$ \\
\hline$R X-03-B B$ & $\begin{array}{l}0.012 \\
0.003 \\
0.010\end{array}$ & $\begin{array}{l}-0- \\
-0- \\
-0-\end{array}$ & $\begin{array}{l}-0- \\
-0- \\
-0-\end{array}$ & $\begin{array}{l}0.003 \\
0.003 \\
0.004\end{array}$ & $\begin{array}{l}-0- \\
-0- \\
-0-\end{array}$ & $\begin{array}{l}0.015 \\
0.006 \\
0.014\end{array}$ \\
\hline LPA-19-73/HGH（14） & $\begin{array}{l}0.007 \\
0.005\end{array}$ & $\begin{array}{l}-0- \\
-0-\end{array}$ & $\begin{array}{l}-0- \\
-0-\end{array}$ & $\begin{array}{l}0.015 \\
0.017\end{array}$ & $\begin{array}{l}-0- \\
-0-\end{array}$ & $\begin{array}{l}0.022 \\
0.022\end{array}$ \\
\hline $\begin{array}{l}\text { RX-03-BB with } \\
\text { LPA-19-73/HGH (14) }\end{array}$ & $\begin{array}{l}0.003 \\
0.005\end{array}$ & $\begin{array}{l}-0- \\
-0-\end{array}$ & $\begin{array}{l}-0- \\
-0- \\
-0\end{array}$ & $\begin{array}{l}0.013 \\
0.017\end{array}$ & $\begin{array}{l}-0- \\
-0-\end{array}$ & $\begin{array}{l}0.016 \\
0.022\end{array}$ \\
\hline LPA-19-87/TONOX $(60 / 40)$ & $\begin{array}{l}0.005 \\
0.001\end{array}$ & $\begin{array}{l}-0- \\
-0-\end{array}$ & $\begin{array}{l}-0- \\
-0-\end{array}$ & $\begin{array}{l}0.004 \\
0.002\end{array}$ & $\begin{array}{l}-0- \\
-0-\end{array}$ & $\begin{array}{l}0.009 \\
0.003\end{array}$ \\
\hline $\begin{array}{l}\text { RX-03-BB with } \\
\text { LPA-19-87/.TONOX }(60 / 40)\end{array}$ & $\begin{array}{l}0.005 \\
0.009\end{array}$ & $\begin{array}{l}-0- \\
-0-\end{array}$ & $\begin{array}{l}-0- \\
-0-\end{array}$ & $\begin{array}{l}0.007 \\
0.008\end{array}$ & $\begin{array}{l}-0- \\
-0-\end{array}$ & $\begin{array}{l}0.012 \\
0.017\end{array}$ \\
\hline LPA-19-87/HGGH-18 & 0.007 & $-0-$ & $-0-$ & 0.041 & $-0-$ & 0.048 \\
\hline $\begin{array}{l}\text { RX-03-BB with } \\
\text { LPA-19/87/HGH-18 }\end{array}$ & $\begin{array}{l}0.006 \\
0.007\end{array}$ & $\begin{array}{l}-0- \\
-0-\end{array}$ & $\begin{array}{l}-0- \\
-0-\end{array}$ & $\begin{array}{l}0.077 \\
0.080\end{array}$ & $\begin{array}{l}-0- \\
-0-\end{array}$ & $\begin{array}{l}0.083 \\
0.087\end{array}$ \\
\hline
\end{tabular}




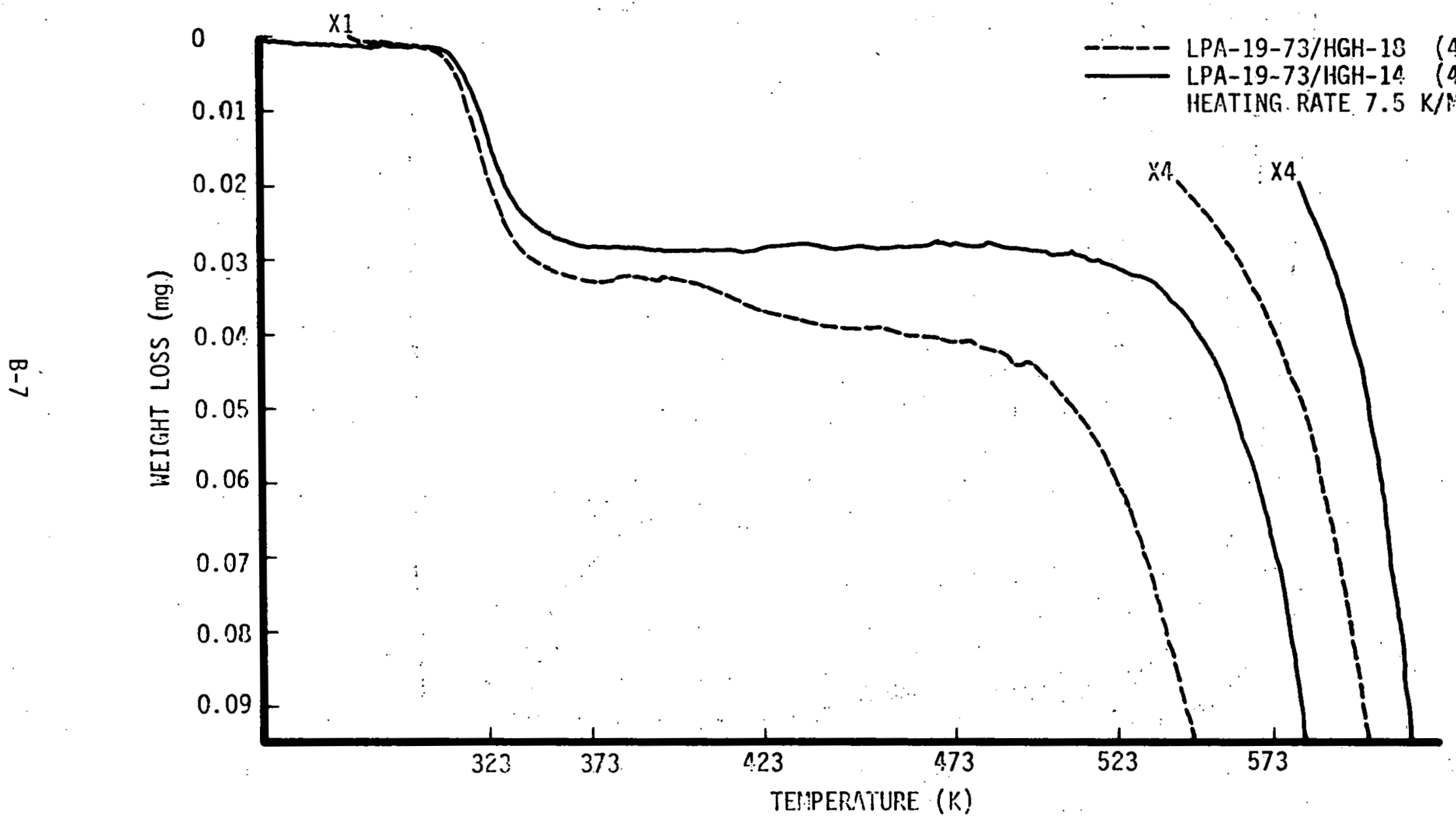

FIG. 1. TA THER!IOGRAMS OF LPA-19-73/IGGH-18 AID LPA-19-73/HGH-19 
- PXX-03-EB WITH LPA-19-37/TOIOXX

- RX-03-BB

HEATIHG PATE 7.5 स/M!I!

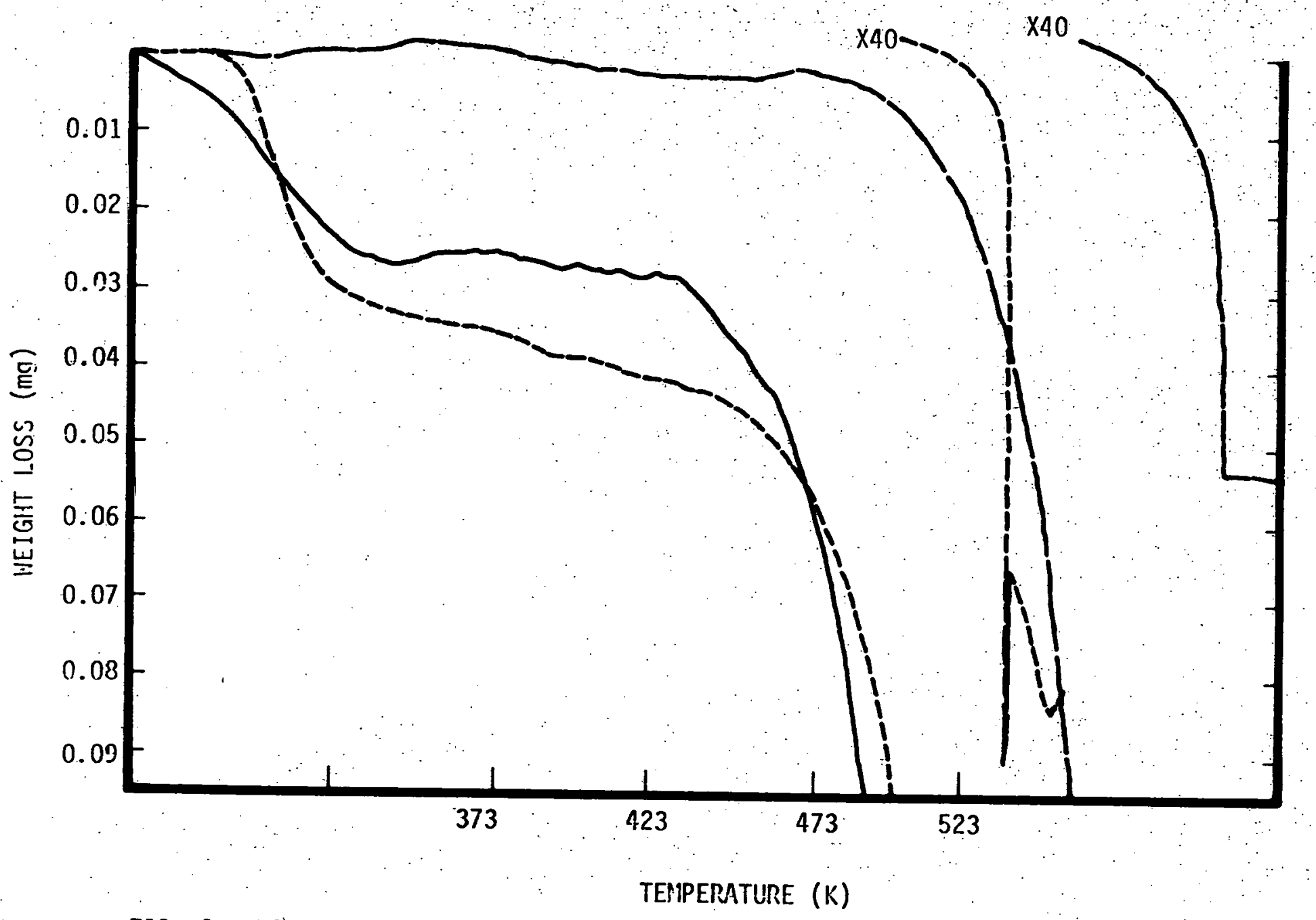

FIG. 2. TA THERHOGPAIS OF RǨ-03-BB, LPA-19-87/TONOX AND RX-03-BB WITH LPA-19-87/TONOX 


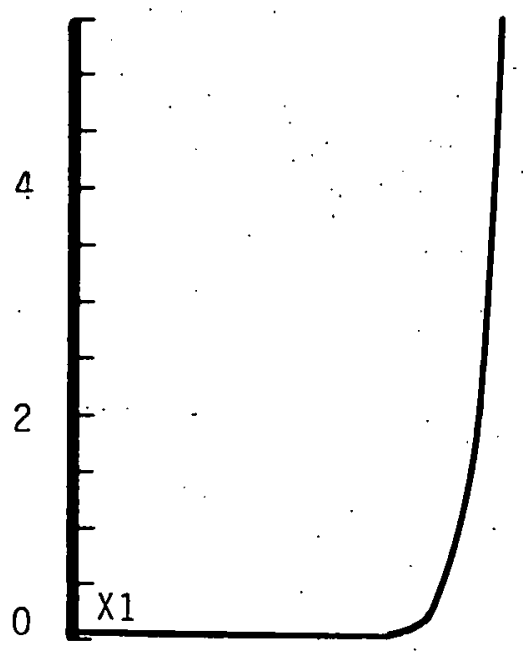

LX-10 HITH

LPA-19-73/HGH-18

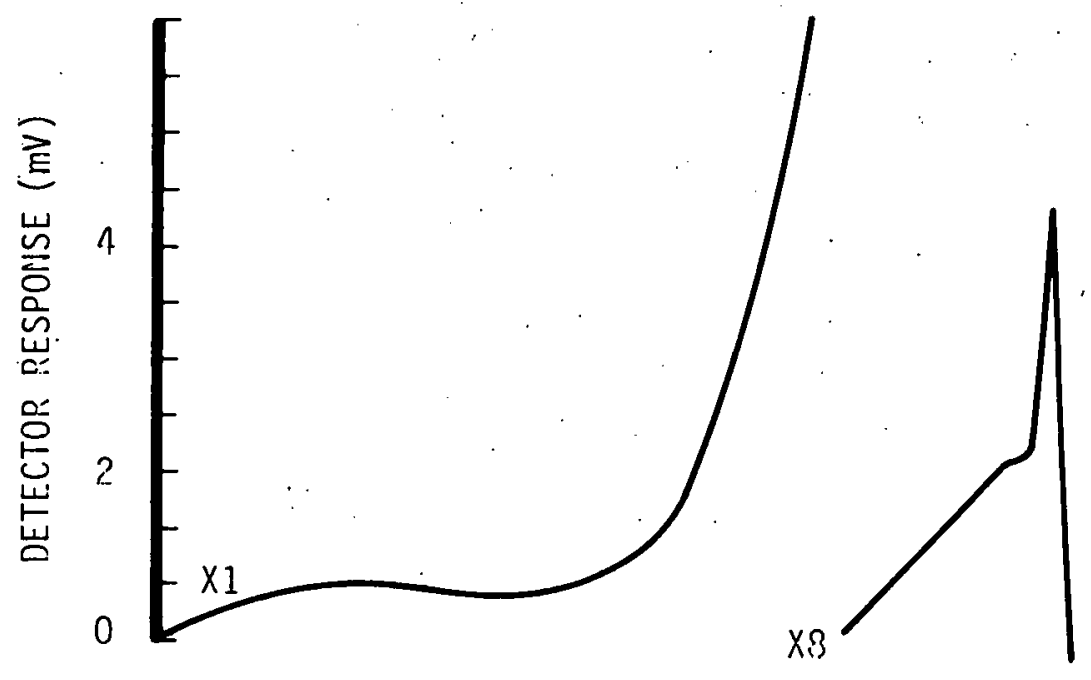

LPA-10-73/HGH-18

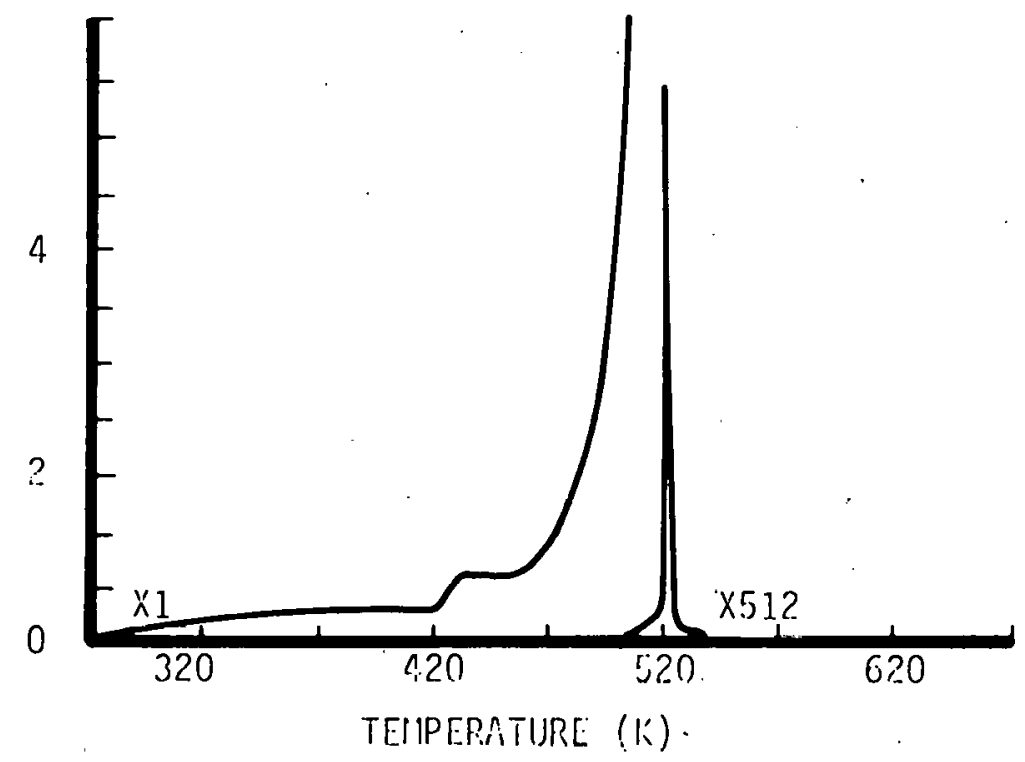

$1 . x-10$

FIG. 3. EFFLUEITT GAS AIIALYSIS OF LX-10, LPA-19-73/I!GI!-18 AIID LX-10 !!ITHI LPA-10-73/!!?H-13 


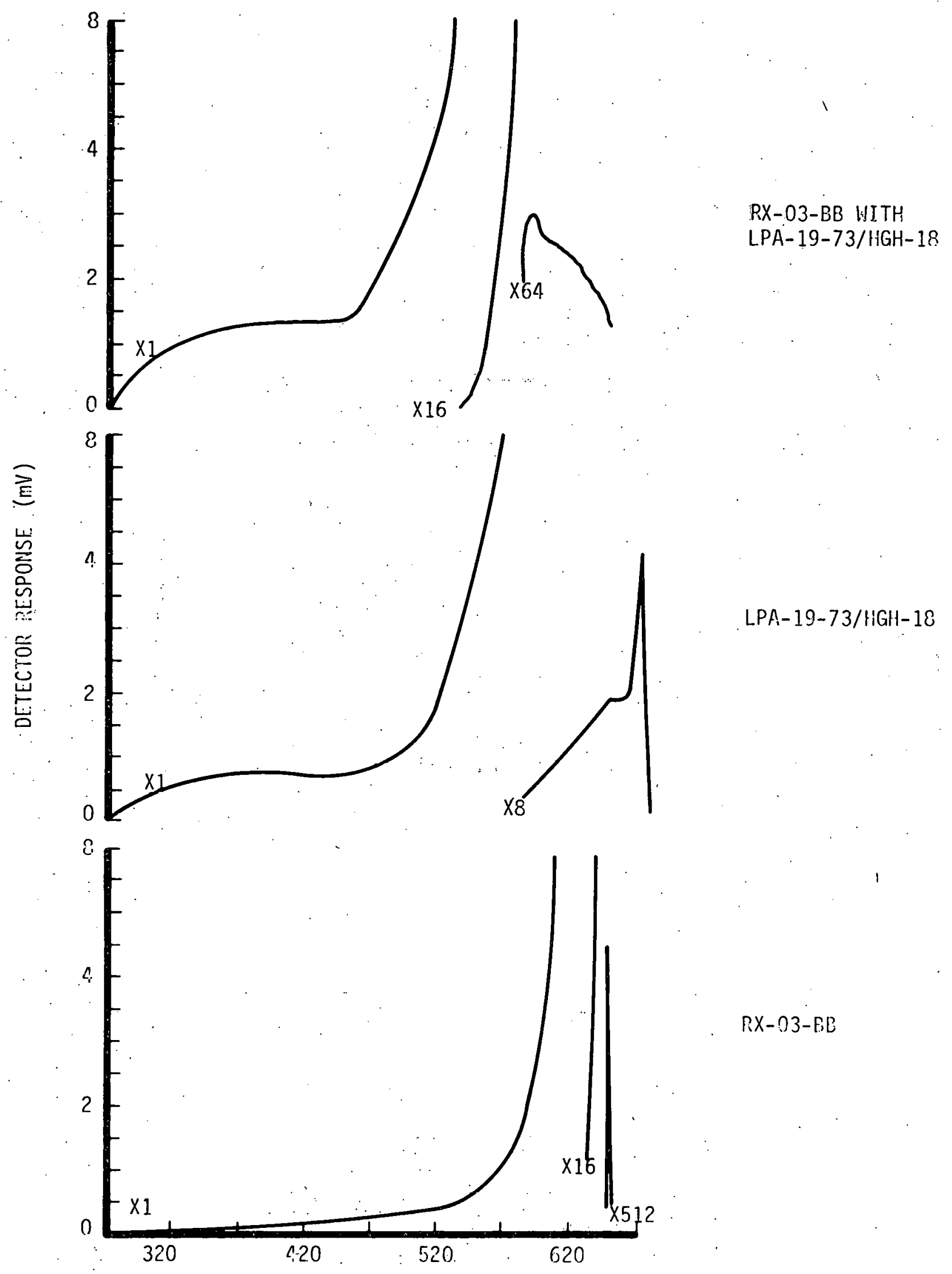

FIG. 4. EFFLUEIT GAS AIALYSIS OF RẌ-03-BB, I.PA-19-73/HGII-18 AND RX-03-ED UIT!! LPA-19-73/HCII-10

$$
\text { B-10 }
$$




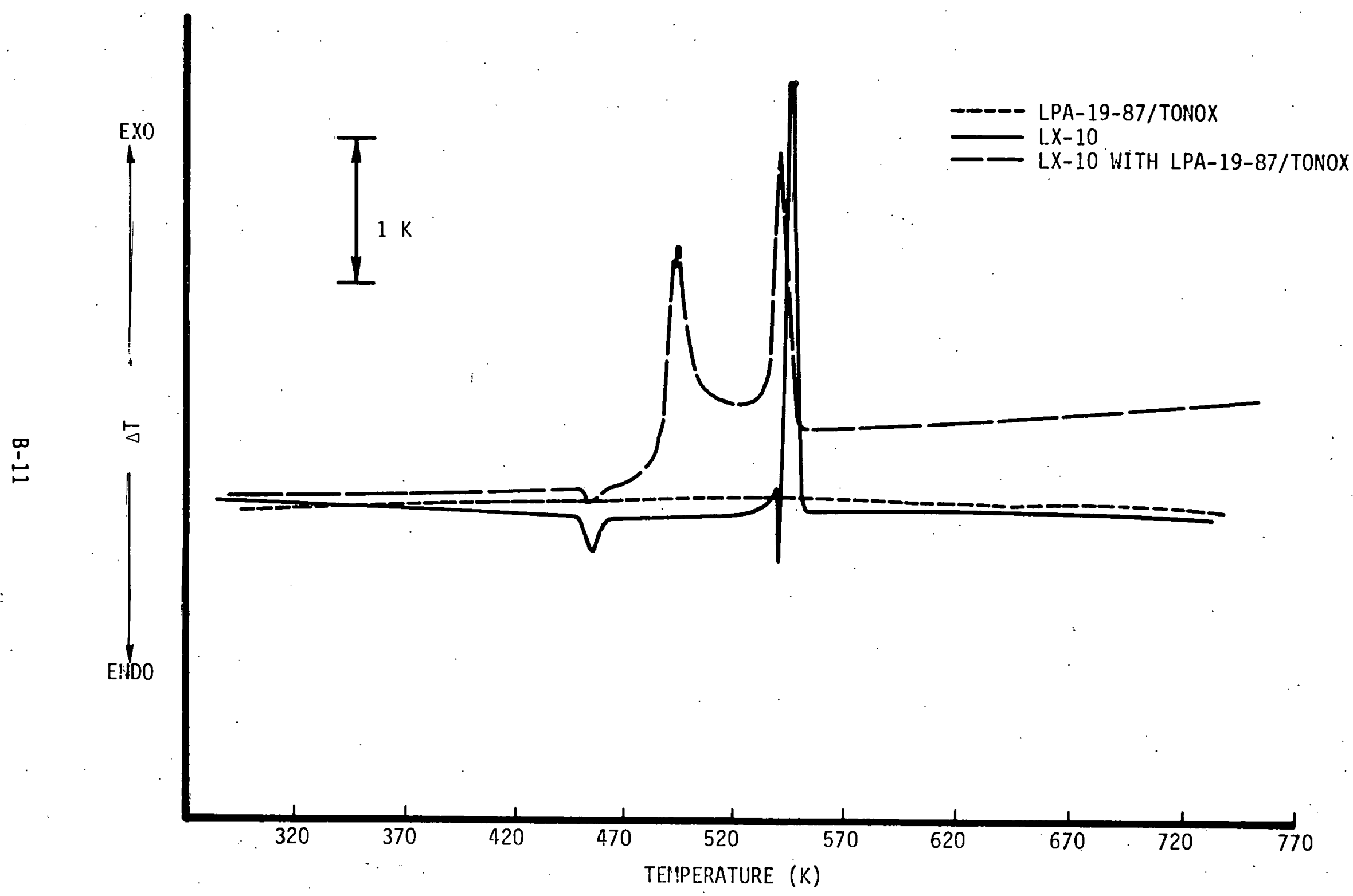

FIG. 5. DTA THERIOGRAMS OF LX-10, LPA-19-37/TONOX AND LX-10 WITH LPS-19-87/TOHOX 


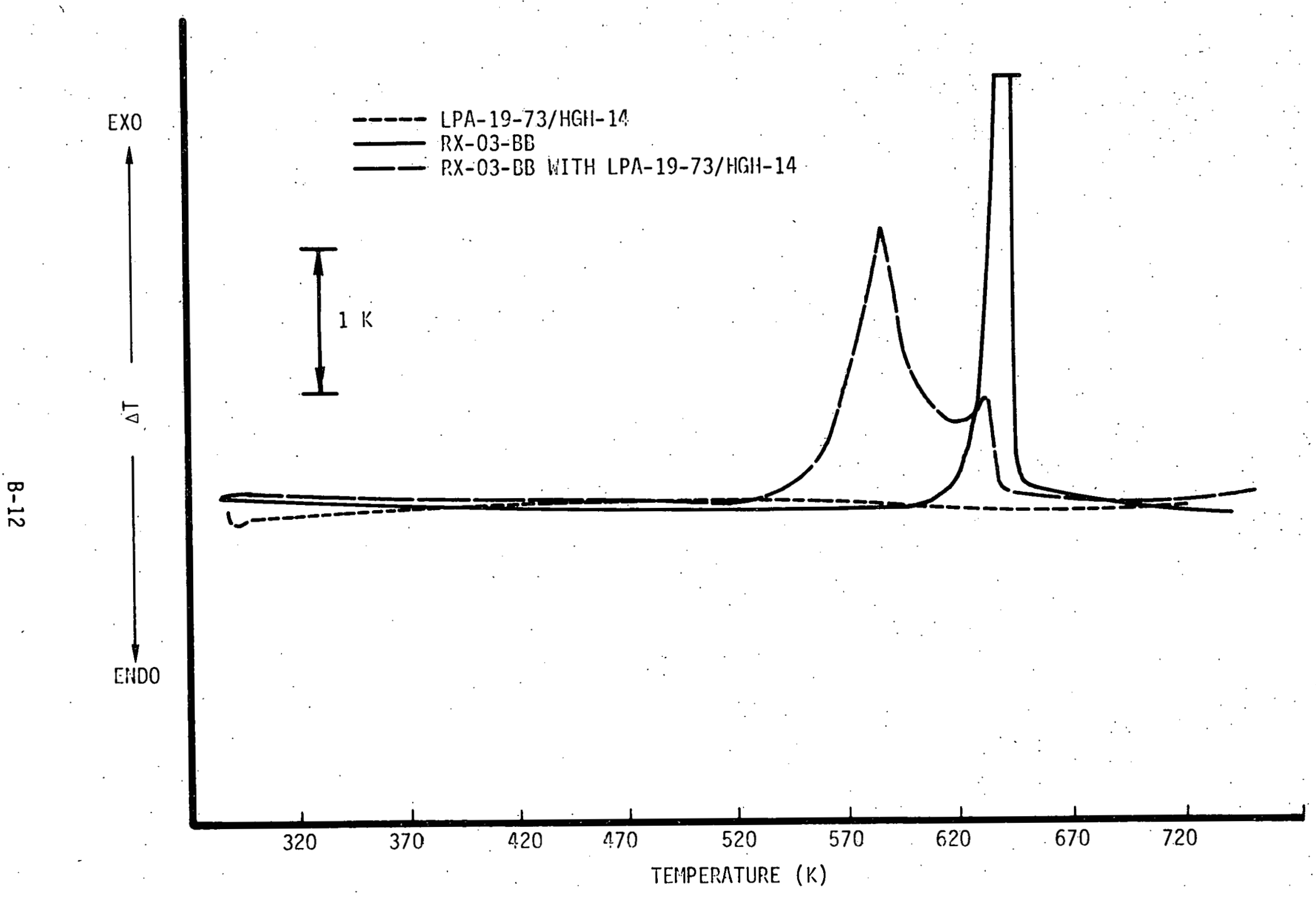

FIG. 6 . DTA THERMOGRAMS OF RX-03-BB, LPA-19-73/HGH-14 ANS RX-03-BB WITH LPA-19-73/HGH-14 
Table III. Henkins Time to Explosion for $L X-10$ with Three Adhesives (Time in Seconds)

\begin{tabular}{|c|c|c|c|c|}
\hline . & $\begin{array}{l}508 \\
(K) \\
\end{array}$ & $\begin{array}{r}513 \\
(\mathrm{~K}) \\
\end{array}$ & $\begin{array}{l}518 \\
(\mathrm{~K}) \\
\end{array}$ & $\begin{array}{l}523 \\
(\mathrm{~K}) \\
\end{array}$ \\
\hline$L X-10$ & $\begin{array}{l}665 \\
491 \\
506 \\
429 \\
\end{array}$ & $\begin{array}{l}334 \\
337 \\
325 \\
347 \\
\end{array}$ & $\begin{array}{l}247 \\
230 \\
278 \\
233 \\
\end{array}$ & $\begin{array}{r}202 \\
209 \\
195 \\
190 \\
\end{array}$ \\
\hline Harmonic Mean & 510 & 336 & 252 & 199 \\
\hline $\begin{array}{l}\text { LX-10 with } \\
\text { LPA-19-87/TONOX }\end{array}$ & $\begin{array}{r}83 \\
276 \\
229 \\
268 \\
\end{array}$ & $\begin{array}{l}48 \\
53 \\
57 \\
61 \\
\end{array}$ & $\begin{array}{l}43 \\
46 \\
47 \\
46 \\
\end{array}$ & $\begin{array}{l}38 \\
36 \\
38 \\
36 \\
\end{array}$ \\
\hline Harmonic Mean & 168 & 54 & 45 & 37 \\
\hline $\begin{array}{l}\text { LX-10 with } \\
\text { LPA-19-73/HGH-14 }\end{array}$ & $\begin{array}{l}361 \\
297 \\
336 \\
356 \\
\end{array}$ & $\begin{array}{l}240 \\
252 \\
214 \\
200 \\
\end{array}$ & $\begin{array}{r}127 \\
97 \\
108 \\
127 \\
\end{array}$ & $\begin{array}{r}114 \\
116 \\
100 \\
\quad 83 \\
\end{array}$ \\
\hline Harmonic Mean & 356 & 225 & 113 & . 101 \\
\hline $\begin{array}{l}\text { LX-10 with } \\
\text { LPA-19-73/HGH-18 }\end{array}$ & $\begin{array}{l}303 \\
298 \\
360 \\
323 \\
\end{array}$ & $\begin{array}{l}225 \\
248 \\
243 \\
240 \\
\end{array}$ & $\begin{array}{r}113 \\
115 \\
102 \\
92 \\
\end{array}$ & $\begin{array}{l}64 \\
67 \\
70 \\
69 \\
\end{array}$ \\
\hline Harmonic Mean & 319 & 239 & 105 & 67 \\
\hline
\end{tabular}




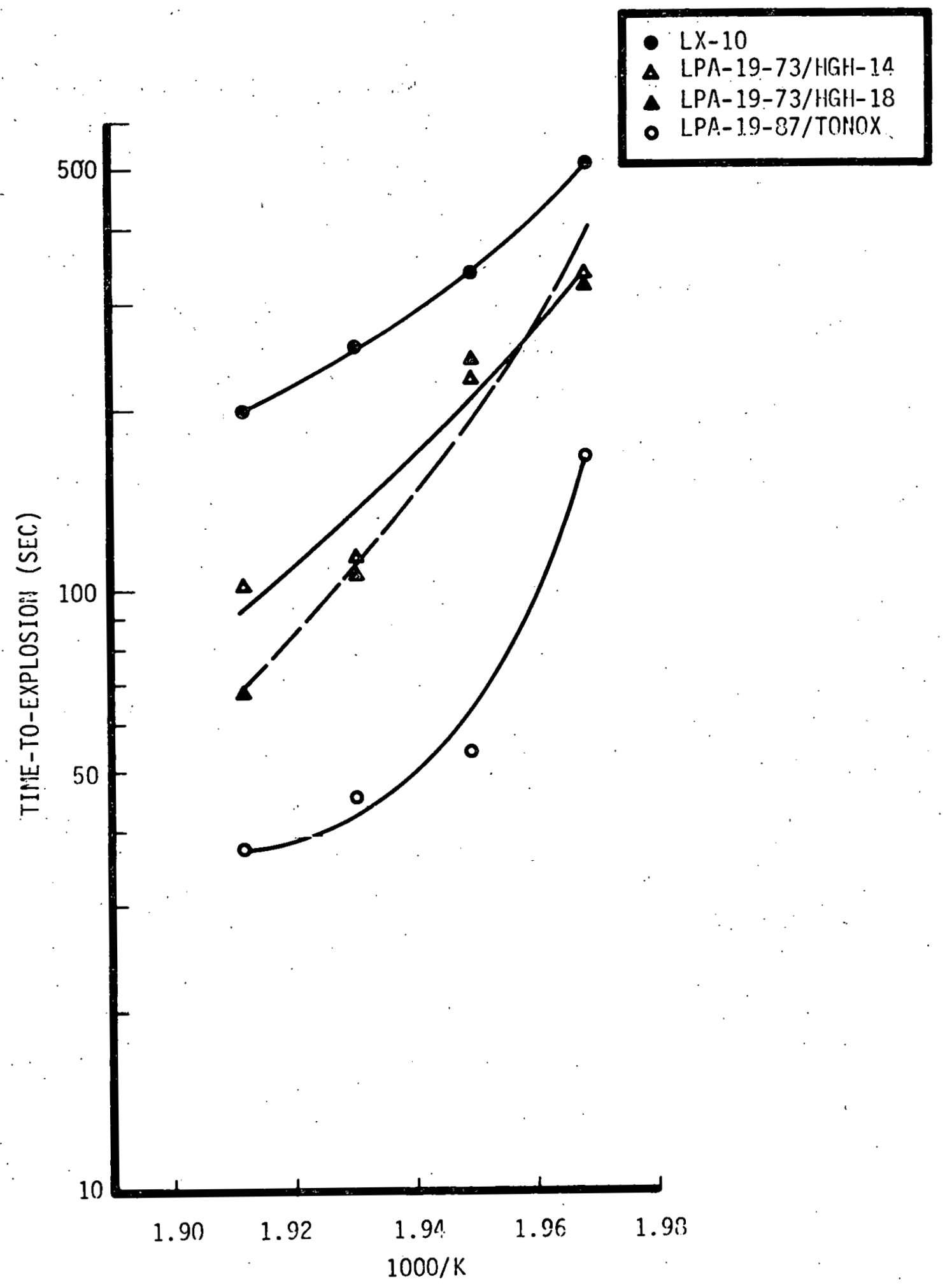

FIG. 7. TIME-TO-EXPLOSION FOR LX-10 AND LX-10 WITH THREE ADHESIVES 
Table IV. Percent Extracted from Three. Adhesives with Acetone and Benzene

LPA-19-73/HGH- 18

LPA-19-87/TONOX

LPA-19-73/HGH-14

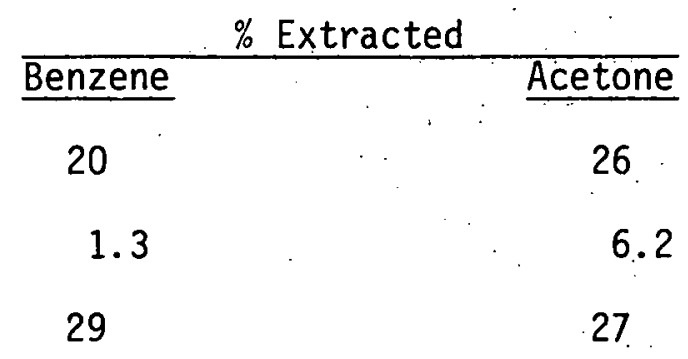


The investigation of the thermal decomposition of PETN was continued and some interesting observations were made. It has previously been reported $(3,4)$ that the rate of thermal decomposition of PETN is particle size dependent, and the data obtained for samples of PETN with different particle size distribution at 393 . K clearly show this dependency.

Last quarter thermal decomposition data were obtained for a sample of PETN with a particle size distribution between 100 and $180 \mu \mathrm{m}$ at 393 , 388,383 and $373 \mathrm{~K}$. This quarter data were obtained using a sample with a particle size distribution ${ }^{a}$ between 60 and $100 \mu \mathrm{m}$ at 393,388 and 383 $K$. The gas evolution data are given in Tables $V$ and $V I$ and plotted in Figs. 8 and 9. There is a difference in the $393 \mathrm{~K}$ data. For the $388 \mathrm{~K}$ data, only two points for the 100 to $180 \mu \mathrm{m}$ sample overlap with the 60 to $100 \mu \mathrm{m}$ data; thus, no conclusion can be made. At $373 \mathrm{~K}$, the data for the two samples are essentially the same indicating that a particle size effect does not exist at this temperature.

To further evaluate the effect of particle size on the rate of decomposition two samples whose particle size difference was much larger were tested. Data for samples with a particle distribution of 30 to $60 \mu \mathrm{m}$ and $>250$ $\mu \mathrm{m}$ at $393,388,383$ and $373 \mathrm{~K}$ are given in Table VII, and as temperature decreases from $393 \mathrm{~K}$ the effect of particle size on the rate of decomposition decreases for this temperature range.

Last quarter the significance of a plot of log time as a function of the reciprocal of the temperature which gave a family of curved lines was discussed $^{b}$. Fig. 10 is a plot obtained by combining all the data from the 60 to $100 \mu \mathrm{m}$ and 100 to $180 \mu \mathrm{m}$ samples. This plot continues to give a curve rather than a straight line indicating the apparent activation energy is different at 388 and $373 \mathrm{~K}$.

To continue the investigation of the thermal decomposition, a $0.5 \mathrm{~kg}$ sample of LX-13-type PETN has been selected for the low temperature decomposition study ( $373 \mathrm{~K}$ and below). The times at temperatures below $373 \mathrm{~K}$ will be long; therefore, glass sample vials with break seals will be used to reduce air leaks.

The sample vials have been purchased and a method of safely sealing the vials has been developed. The samples will be conditioned at various temperatures for preselected times. Then their atmospheres will be analyzed as will the remaining solids.

(3) L. C. Myers, Thermal Properties (MHSMP-75-16).

(4) L. C. Myers, Thermal Properties (MHSMP-75-36A).

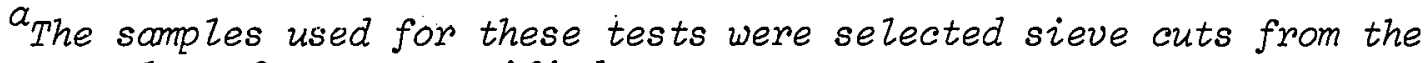
same. Lot of Pantex purified PETN.

${ }^{b}$ If the decomposition mechanism is independent of temperature and the extent of the reaction, a family of straight lines would be obtained. 
Table V. Gas Evolved from PETN Samples of Different

Particle Sizes at 393 and $388 \mathrm{~K}$

(Volume of Gas in me)

(Corrected to STP

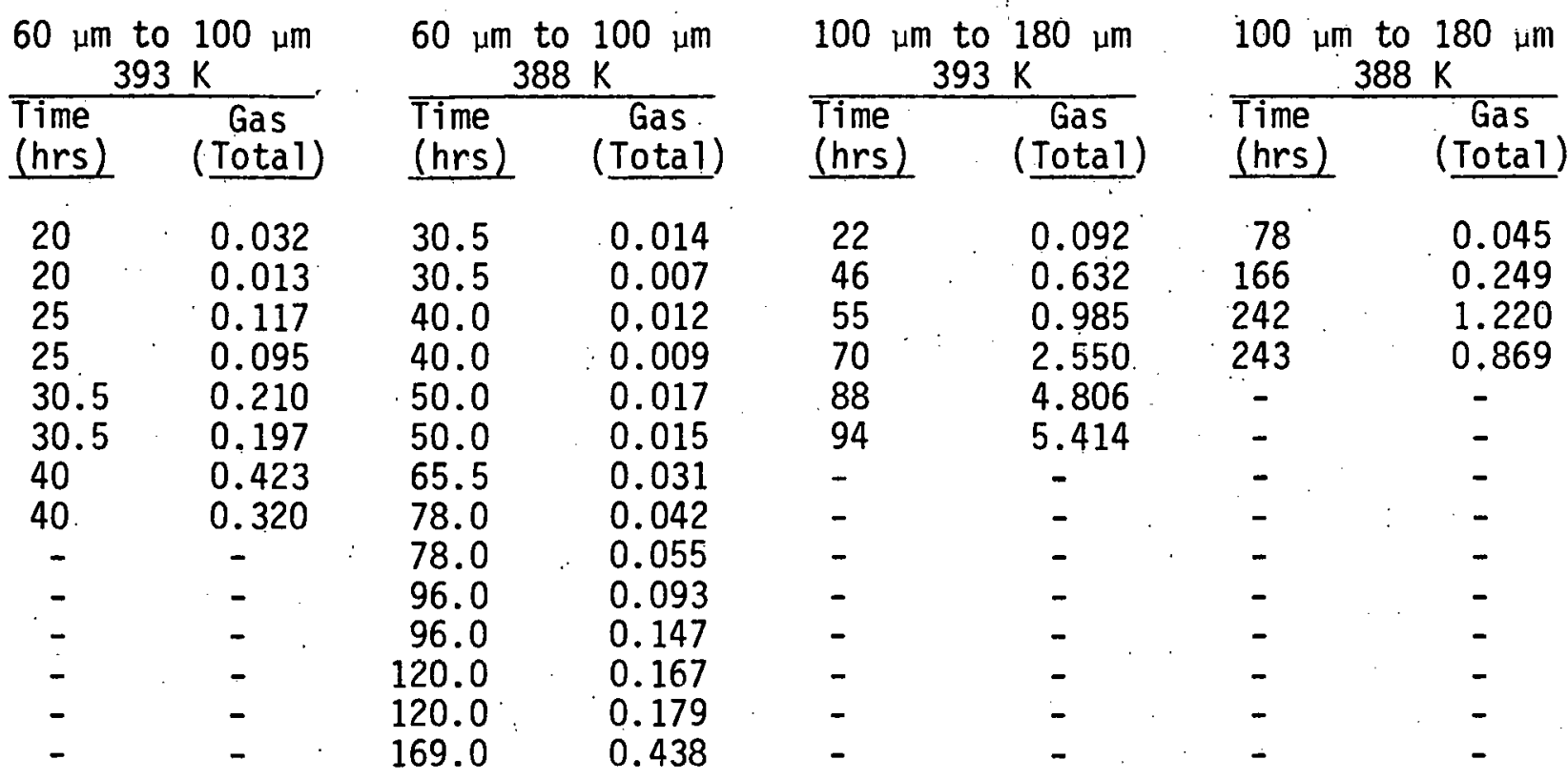

Table VI: Gas Evolved from PETN Samples of Different Particle Sizes at 383 and $373 \mathrm{~K}$

(Volume of Gas in $\mathrm{ml}$.)

(Corrected to STP)

$60 \mu \mathrm{m}$ to $100 \mu \mathrm{m} \quad 100 \mu \mathrm{m}$ to $180 \mu \mathrm{m} \quad 100 \mu \mathrm{m}$ to $180 \mu \mathrm{m}$

$\begin{array}{ll}\frac{383 K}{\text { Time }} & \text { Gas } \\ \text { (hrs) } & \text { (Total) }\end{array}$

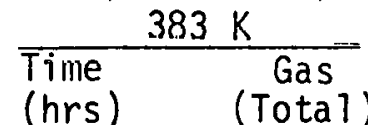

Time
(hrs)

143

0.026

22

0.006

118

0.002

143

0.020

- 46

0.013

673

0.063

167

0.031

94

0.012

768

0.068

191

0.028

166

0.029

936

0.056

191

0.032

190

0.028

1150

0.054

0.118

265

0.044

214

265

0.050

$-$

313

0.045

313

503

0.064

503

0.133

958

0.135

958

0.156

0.250

1342

0.111

0.159 


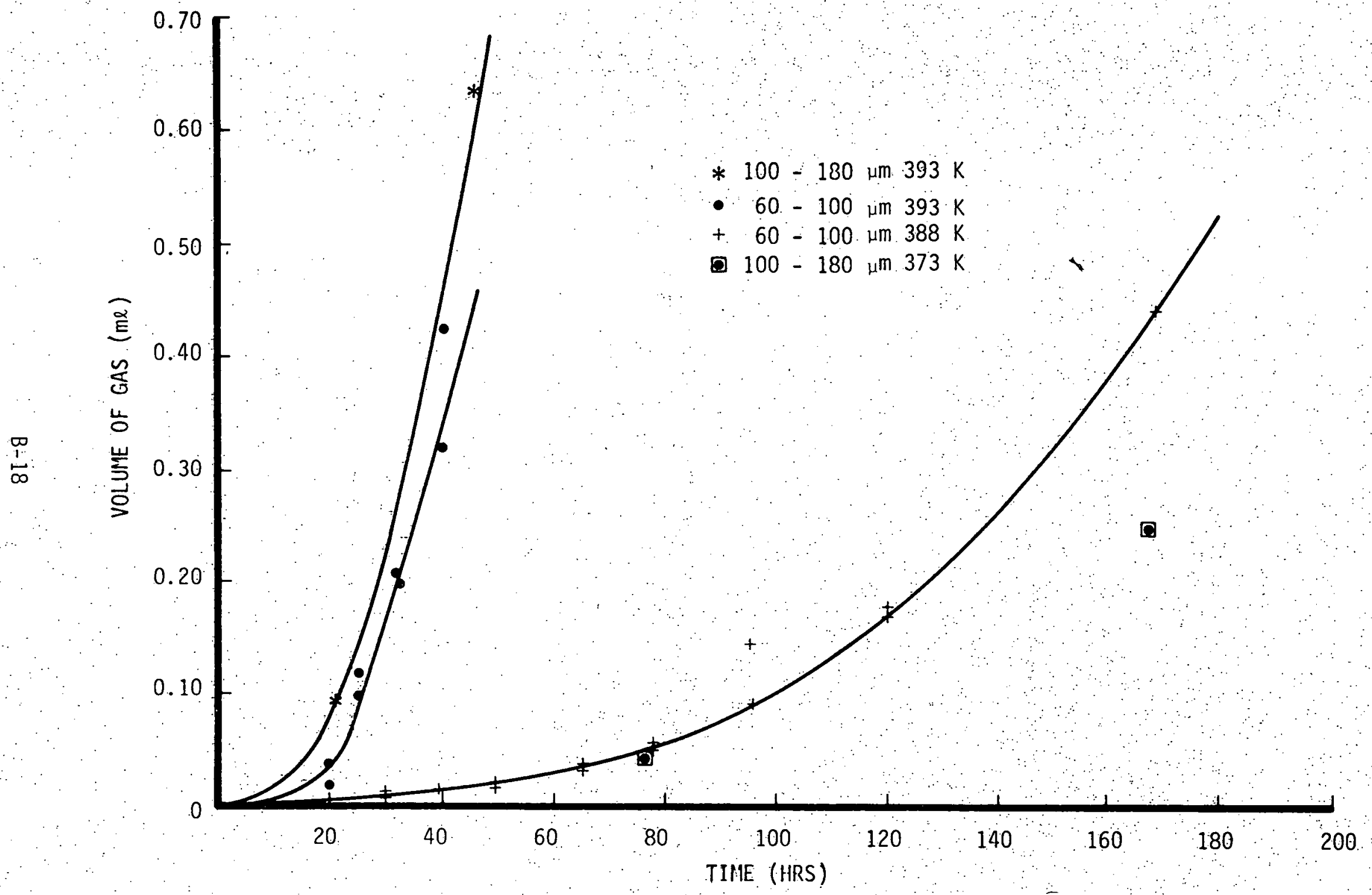

FIG. 8. GAS EVOLVED BY PETN AS A FUNCTION OF TIME 


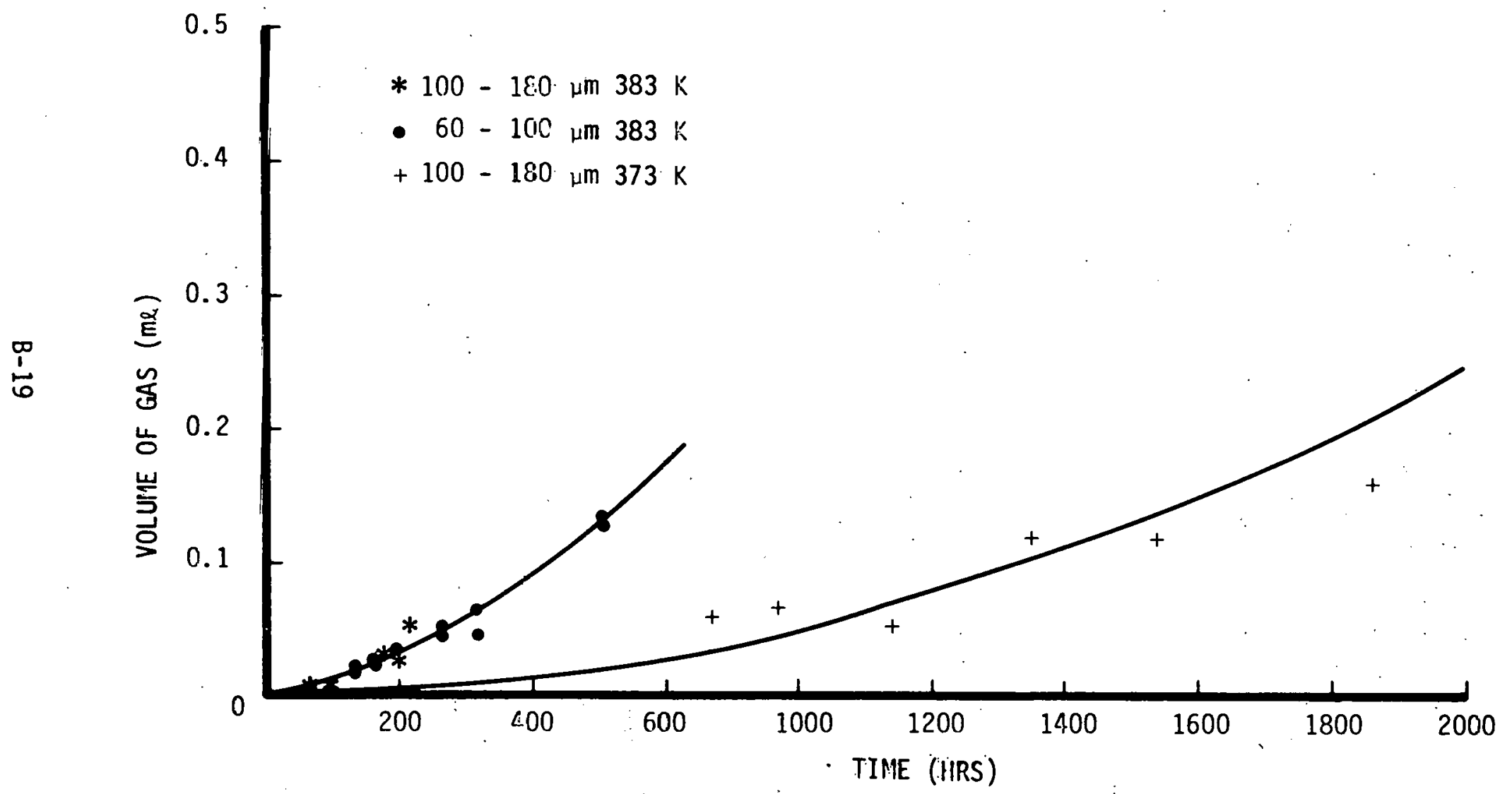

FIG. 9. GAS EVOLVED BY PETII AS A FUIICTIOH OF TIME 
Table. VII. Chemical Reactivity Test Data for PETN Sample with Different Particle Size

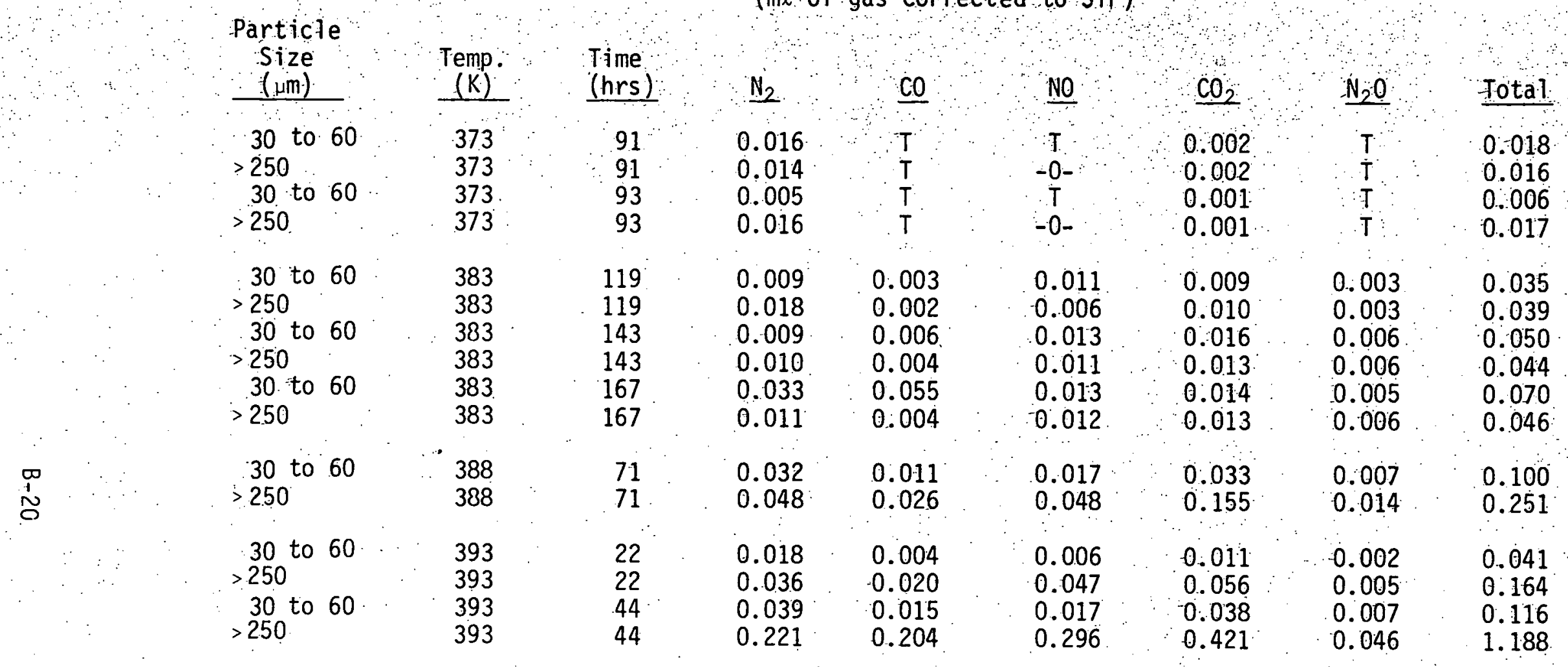




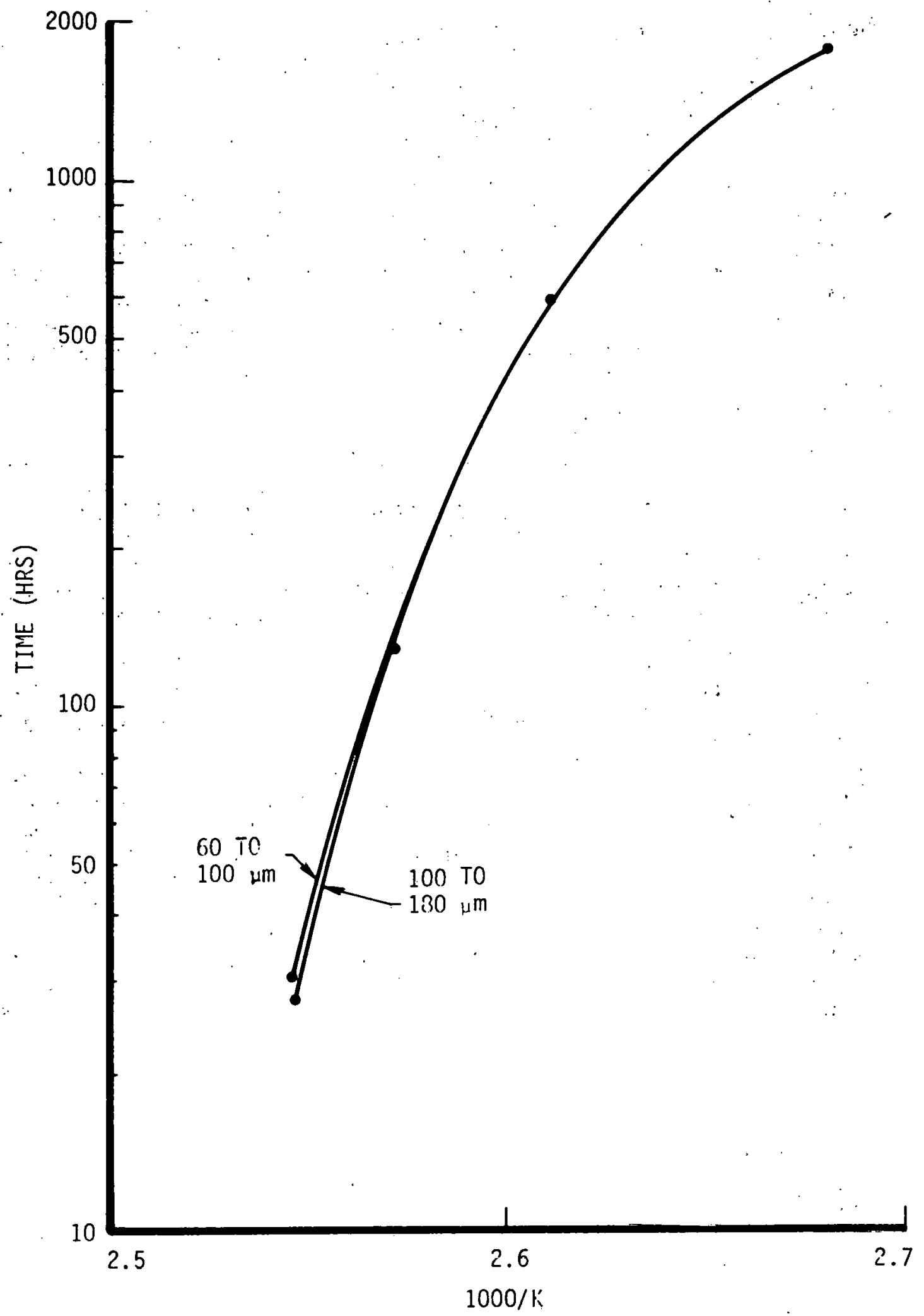

FIG. 10. LOGARITHM OF TIIIE AS A FUNCTIOH OF'THE RECIPROCAL TEIIPERATURE FOR A GIVEN EXTENT OF RF.ACTIOH OF PETI! 


\section{VARIATIONS IN THE CHEMICAL REACTIVITY TEST DATA}

Last quarter data were reported indicating that some of the variations in the PBX 9404 data could be due to the position of the sample in the oil bath, the order in which the samples were run or changes in the sensitivity of the thermal conductivity detector. A more detailed. investigation was made into the reproducibility of the gas chromatograph. The reproducibility of the calibrations was checked and the data are given in Table VIII. Variations in these data may be caused by changes in the instrument sensitivity, the reproducibility of the pressure manometer used to determine the gas pressure in the calibration loop, and fluctuations in temperature. The standard deviation for these data is less than or equal to $2 \%$ of the mean. In the past a standard deviation of 2 to $5 \%$ for chemical reactivity data has been acceptable and these calibration constants were considered adequate.

A series of runs was made on a mixture of $\mathrm{N}_{2}$ and $\mathrm{N}_{2} \mathrm{O}$, The results of these tests are given in Table. IX and there appear to be some trends. The sensitivity of the instruments reaches a maximum at 1500 each day. For three days the sensitivity of the instrument continued to increase and on August 8 the sensitivity changed by about 9\%, Such a change is not considered normal and the instrument will be checked in the near future to determine if there are some bad components causing such a sudden change in the sensitivity.

The tests with the standard indicate that it should be posisibie to improve the PBX 9404 data by running a standard just before and after each PBX 9404 run and using these standards to normalize the PBX 9404 data. Table $X: g$ ives the results from such runs and the normalization did improve the PBX 9404 data. The standard deviation was changed from 0.015 to $0.005 \mathrm{me}$. This is another indication that there is some instability in the instrument, and a check will be made to determine if it is an electronic problem which can be corrected, If the problem cannot be corrected, then it may be necessary to add an internal standard to each sample so the data can be more accurately normalized. By adding another gas sampling valve, a known volume of neon could be injected with each sample. The run could be normalized to a given volume of neon. Neon would not interfere with the other compounds of interest. 
Table.VIII. Calibration Constants for the Chemical Reactivity Test (Corrected to STP)

\begin{tabular}{|c|c|c|c|c|c|}
\hline & \multicolumn{5}{|c|}{ Count $/ \mathrm{ml} \times 10^{-3}$} \\
\hline & $\overline{\mathrm{N}_{2}}$ & $\underline{\mathrm{CO}}$ & NO & $\underline{\mathrm{CO}_{2}}$ & $\underline{\mathrm{N}_{2} \mathrm{O}}$ \\
\hline $7-14-75$ & 117.7 & 122.5 & 112.8 & 1.41 .3 & 144.5 \\
\hline $7-21-75$ & 118.6 & 120.7 & 112.1 & 143.2 & 148.5 \\
\hline $7-28-75$ & 116.4 & 118.3 & 107.9 & 139.8 & 142.4 \\
\hline $8-04-75$ & 121.7 & 122.2 & 111.5 & 144.5 & 149.4 \\
\hline $8-11-75$ & 117.2 & 117.8 & 109.0 & 139.1 & 142.5 \\
\hline $8-18-75$ & 118.9 & 119.9 & 110.9 & 141.9 & 146.4 \\
\hline & $\therefore$ & & & & \\
\hline Mean & 118.4 & 120.2 & 110.7 & 141.6 & 145.6 \\
\hline$\sigma$ & 1.85 & 1.95 & 1.89 & 2.03 & 2.98 \\
\hline
\end{tabular}


Table IX, Calibration Constants for Chemical Reactivity Test Apparatus

\begin{tabular}{|c|c|c|c|}
\hline Date & Time & $\begin{array}{l}\text { Count } \\
\underline{N_{2}}\end{array}$ & $\begin{array}{r}10^{-3} \\
\mathrm{~N}_{2} \mathrm{O} \\
\end{array}$ \\
\hline $8-4-7.5$ & $12: 00$ & 126.2 & 151.8 \\
\hline $8-5-75$ & $\begin{array}{r}9: 30 \\
12: 00 \\
12: 30 \\
13: 45 \\
15: 00 \\
15: 30\end{array}$ & $\begin{array}{l}127.8 \\
127.0 \\
126.7 \\
129.1 \\
130.4 \\
128.3\end{array}$ & $\begin{array}{l}151.8 \\
153.2 \\
152.3 \\
155.13 \\
157.3 \\
153.0\end{array}$ \\
\hline $8-6-75$ & $\begin{array}{r}9: 30 \\
12: 00 \\
12: 30 \\
13: 45 \\
15: 00 . \\
15: 30\end{array}$ & $\begin{array}{l}129.1 \\
128.3 \\
127.7 \\
131.3 \\
132.3 \\
129.9\end{array}$ & $\begin{array}{l}154.3 \\
155.8 \\
153.3 \\
158.0 \\
156.1 \\
154.2\end{array}$ \\
\hline $8-7-75$ & $\begin{array}{r}9: 30 \\
12: 00 \\
12: 30 \\
13: 45 \\
15: 00 \\
15: 30\end{array}$ & $\begin{array}{l}128.6 \\
129: 4 \\
128.3 \\
131.7 \\
133.6 \\
131.4\end{array}$ & $\begin{array}{l}155.0 \\
153.9 \\
157.8 \\
158.1 \\
158.2 \\
157.8\end{array}$ \\
\hline $8-8-75$ & $\begin{array}{r}9: 30 \\
12: 00 \\
12: 30 \\
.13: 45 \\
15: 00 \\
15: 30\end{array}$ & $\begin{array}{l}120.9 \\
120.0 \\
119.5 \\
122.3 \\
122.9 \\
121.4\end{array}$ & $\begin{array}{l}145.3 \\
144.2 \\
143.4 \\
150.5 \\
147.0 \\
144.8\end{array}$ \\
\hline
\end{tabular}


Table X. Chemical Reactivity Test Data for PBX 9404 and Standard Mixture (me of gas corrected to STP)

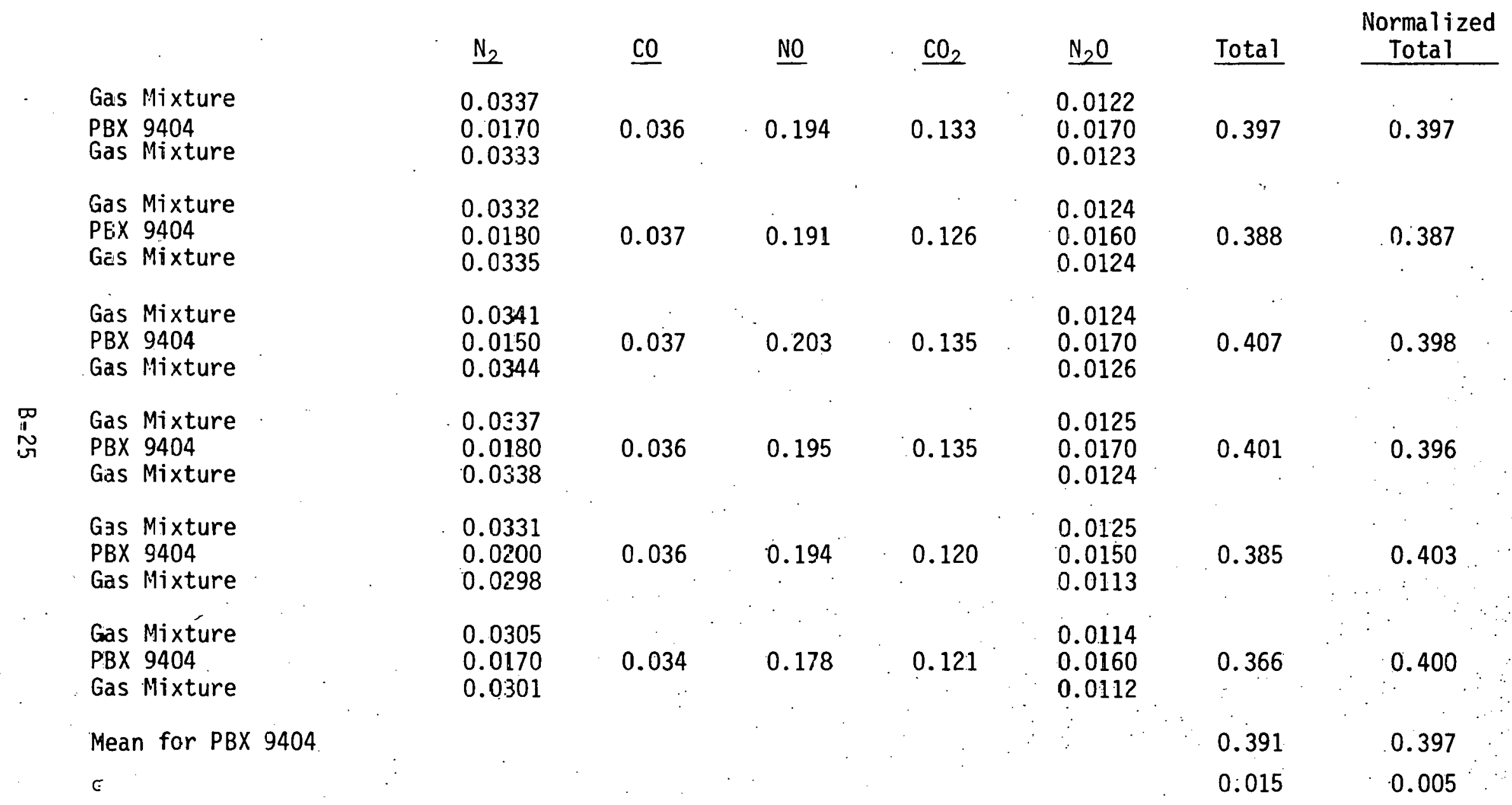




\section{FUTURE WORK, COMMENTS, CONCLUSIONS}

Three adhesive formulations were prepared by LLL and Pantex was requested to do a complete thermal evaluation of the adhesive with $L X-10$ and $R X-$ 03-BB. The chemical reactivity test data indicate some reactivity between $L X-10$ and samples of LPA-19-87/TONOX and LPA-19-7/HGH-18. There was no indication that $L P A-19-7 / H G H-14$ was reacting with $L X-10$ or that any of the three were reactive with $R X-03-B B$. Thermogravimetric analysis, $T A$, shows that each adhesive has some absorbed water (ranged from 0.4 to $0.8 \%$ ): LPA-99-73/HGH-14 is more stable than the other two adhesives.

Effluent gas analysis, TA and DTA show a lowering of both explosive decomposition temperatures when mixed with the adhesives, indicating that they are reactive at elevated temperatures. However, this is normal for urethanes such as Adiprene $L-100$ and it is not considered to be an indication of a compatibility problem.

The Henkin times-to-explosion for $L X-10$ with the three adhesives also indicates that there is some reactivity at the higher temperatures but again, this has been observed with Adiprene $L-167$ and $L-100$.

The acetone and benzene extractables were determined using a soxhlet apparatus. Two of the adhesives, LPA-79-73/HGH-14 and LPA-19-73/HGH-18, had 20 to $29 \%$ extractables. The significance of this will depend on the types of applications in which the adhesive will be used.

There are a few more tests to be conducted such as thermal mechanical analyses and identification of the extractables, volatile components and decomposition products.

Some additional thermal decomposition data for PETN show that sample particle size only affects the rate of decomposition above $383 \mathrm{~K}$. However, the results continue to indicate that the decomposition reaction mechanism is dependent on temperature or on the extent of the reaction.

A sample of PETN has been selected for the investigation of the thermal decomposition at $373 \mathrm{~K}$ and below. It has been purified by recrystallizing from acetone and then made into an LX-13 type PETN.

Plans have been made to seal PETN samples in glass vials with break seals and these have been purchased for the investigation. This should eliminate leaky sample holders which have caused problems in the past. The sealing of the sample vials will begin in the very near future.

Some chemical reactivity data collected this quarter indicate that the sensitivity of the thermal conductivity detector is changing and causing some of the variations in the PBX 9404 data. From the data given the sensitivity of the detector seems to reach a maximum about 1500 each day, and at times there are large changes $(9 \%)$ observed. 
A series of tests was made ușing PBX 9404 and a standard gas mixture. Six runs made on different days had a standard deviation changed from $0.015 \mathrm{me}$. By normalizing the data the standard deviation was reduced to 0.005 me which is $1.2 \%$ of the mean.

The chemical reactivity instrument will be checked to determine if the variation is an electronic problem and can be corrected. If it cannot be corrected an internal standard can be added to each sample to normalize the data. This can be accomplished by adding another gas sampling valve and introducing a known amount of neon into each run. 